\title{
Being together in youth worship: An empirical study in Protestant Dutch contexts
}

\begin{tabular}{|c|c|}
\hline \multicolumn{2}{|c|}{$\begin{array}{l}\text { Authors: } \\
\text { Ronelle Sonnenberg }{ }^{1} \\
\text { Malan Nel }^{2} \\
\text { Jos de Kock } \\
\text { Marcel Barnard }{ }^{4,5,6}\end{array}$} \\
\hline \multicolumn{2}{|c|}{$\begin{array}{l}\text { Affiliations: } \\
{ }^{1} \text { Research Center Youth, } \\
\text { Church, Culture (OJKC) at } \\
\text { the Protestant Theological } \\
\text { University (PThU), The } \\
\text { Netherlands }\end{array}$} \\
\hline \multicolumn{2}{|c|}{$\begin{array}{l}\text { ²Department of Practical } \\
\text { Theology, Faculty of } \\
\text { Theology, University of } \\
\text { Pretoria, South Africa }\end{array}$} \\
\hline \multicolumn{2}{|c|}{$\begin{array}{l}{ }^{3} \text { Department of Practical } \\
\text { Theology of the Protestant } \\
\text { Theological University } \\
\text { (PThU), The Netherlands } \\
\text { and Research Center Youth, } \\
\text { Church, Culture (OJKC) }\end{array}$} \\
\hline \multicolumn{2}{|c|}{$\begin{array}{l}{ }^{4} \text { Department of Practical } \\
\text { Theology of the Protestant } \\
\text { Theological University } \\
\text { (PThU), The Netherlands }\end{array}$} \\
\hline \multicolumn{2}{|c|}{$\begin{array}{l}{ }^{5} \text { Liturgical Studies at VU } \\
\text { University, The Netherlands }\end{array}$} \\
\hline \multicolumn{2}{|c|}{$\begin{array}{l}{ }^{6} \text { Department of Practical } \\
\text { Theology, University of } \\
\text { Stellenbosch, South Africa }\end{array}$} \\
\hline \multicolumn{2}{|c|}{$\begin{array}{l}\text { Note: } \\
\text { This article is based on a } \\
\text { part of Ronelle Sonnenberg's } \\
\text { PhD thesis 'Youth worship } \\
\text { in protestant contexts. A } \\
\text { practical theological theory of } \\
\text { participation of adolescents' } \\
\text { (2015). Her supervisors were } \\
\text { Prof. M. Barnard, Prof. M. Nel } \\
\text { and Dr A. de Kock. Prof. Nel } \\
\text { is Extraordinary Professor in } \\
\text { the Department of Practical } \\
\text { Theology at the University of } \\
\text { Pretoria, South Africa, and } \\
\text { former director/founder of } \\
\text { the Centre for Contextual } \\
\text { Ministry, Faculty of Theology, } \\
\text { at the same university. } \\
\text { This article is published in the } \\
\text { section Practical Theology } \\
\text { of the Society for Practical } \\
\text { Theology in South Africa. }\end{array}$} \\
\hline 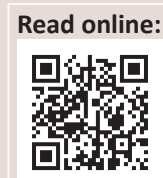 & $\begin{array}{l}\text { Scan this QR } \\
\text { code with your } \\
\text { smart phone or } \\
\text { mobile device } \\
\text { to read online. }\end{array}$ \\
\hline
\end{tabular}

In a qualitative empirical research project on youth worship, we discovered that 'being together' is primary quality of youth worship. This primary quality consists of at least four aspects. Firstly, community is celebrated through physical presence. More specifically, the physical presence of siblings plays an important part in the participation of youth in worship. Secondly, an empathetic and emotional aspect is essential for adolescents. 'Being together' in youth worship means being together in unity and trust and in equality, as kindred spirits. Thirdly, 'being together' in youth worship yields possibilities to cross social and ecclesiological boundaries. Fourthly, there is a theological aspect in 'being together' that could be described as 'sharing faith and being in God's presence'.

\section{Introduction}

In this practical theological and qualitative empirical study, we have investigated the participation of adolescents in youth worship in Protestant contexts in the Netherlands; for example, their joining in a youth band, or the meaning they attribute to a prayer in youth worship. The empirical part of the study consists of an elaborated explorative field study amongst adolescents participating in 18 different worship gatherings in local churches and national events. It appeared that the participation of youth in youth worship is characterised by three primary qualities: 'learning faith' (Sonnenberg \& Barnard 2012), 'recreation' (Sonnenberg \& Barnard 2015), and 'being together'. ${ }^{1}$ In this article, we present the results of the third quality.

We focused on social interactions, relations, and community experiences in youth worship gatherings. We asked about the type of interactions in youth worship that were taking place, what they meant for the participation of adolescents and how these aspects could be understood from a sociological as well as from a theological perspective. Being together is a feature of Christian worship in general (Hahn 1970:34) ${ }^{2}$ and, thus, also holds for youth worship, as we will explain. We will recall theories of F.D.E. Schleiermacher about the social character of the church. The main question asked in this article is: What aspects can be distinguished in the quality of 'being together' in youth worship and how can they be understood sociologically and theologically?

We observed that there are different types of youth worship. Some are organised for categorical sub-groups whereas others are gatherings for the entire congregation. ${ }^{3}$ In the Bible corporate thinking is obvious. In terms of Nel 'God thinks ecclesiologically' (Nel 2000:16) ${ }^{4}$ and the unity of his people 'is a witness to his glory' (Nel 2000:16). We can also refer to unity as one of the classical nota ecclesiae. In practice, however, youth worship is directed at only a part of the congregation. The reasons for this limitation are clear. Adolescents often experience a gap

\footnotetext{
1.Van Wijnen (2013) speaks of being-together as a basic datum.

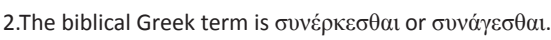

3.Emery-Wright describes best practice and faced dangers of those models in (Emery-Wright 2012:159-176).
}

4.See, for the theological argumentation, also ages pp. 85-88.

Correspondence to: Ronelle Sonnenberg

Email: pmsonnenberg@pthu.nl

Postal address: Postbus 7161, 1007 MC Amsterdam, The Netherlands

Dates: Received: 08 Oct. 2014 | Accepted: 06 June 2015 | Published: 31 Aug. 2015

How to cite this article: Sonnenberg, P.M., Nel, M., De Kock, A. \& Barnard, M., 2015, 'Being together in youth worship: An empirical study in Protestant Dutch contexts', HTS Teologiese Studies/Theological Studies 71(2), Art. \#2832, 10 pages. http://dx.doi.org/10.4102/ hts.v71i2.2832

Copyright: @ 2015. The Authors. Licensee: AOSIS OpenJournals. This work is licensed under the Creative Commons Attribution License. 
between their preferences of celebrating and the worship style in regular worship. Further, they miss the presence of peers in many Dutch congregations, which have many senior members, whilst participating in peer groups is essential for adolescents (Scholte \& Engels 2007:97). Moreover, modern culture since the middle of the 19th century has defined youth as a distinguished social category (Senter et al. 2001:126; Van Lieburg 2012:20-23, 32-34). Further, late-modern culture in general is characterised by many social differentiations and networks. People eclectically choose the networks in which they want to participate. For all these reasons, suitable methods of youth worship are searched. Later on in this article, we will propose that the ideal of unity can be met by stimulating and enhancing the crossing of social and ecclesiological boundaries.

The first part of this article provides a review of the theoretical background of the quality 'being together', followed by an outline of the research methodology. The middle section consists of the presentation of findings of the empirical qualitative study. The final section provides reflections and conclusions.

\section{Theoretical background}

In the explorative phase of the research, we noticed in our field notes and interviews the importance of community experience and of interaction with peers. The question 'Who participates?' became relevant, as well as, 'What interactions take place?' In an iterative process of, on the one hand, collecting and analysing empirical qualitative data and, on the other hand, making use of the literature, four aspects of 'being together' in youth worship were developed. In this section, we will discuss the theoretical background in four aspects, namely:

1. physical presence

2. empathetic and emotional equality

3. the opportunity to cross social and ecclesiological boundaries

4. and sharing faith.

\section{Physical presence}

In recent publications about religious (youth) communities the aspect is referred to of virtual communities and translocal communities (Cloete 2015; De Kock 2015). The digital culture affects structures of authority and puts forward a de-embodied form of participation. We acknowledge the influence of these in the way of being together. In our article 'shaping youth worship' (Sonnenberg et al. 2014) we extensively reflect on youth worship in the frame of the network culture, which includes the digital world, a 'plural authority structure' and a connection between local and translocal participation. However, we now describe the physical communities. These communities connect with digital communications, for example, when friends make online appointments to visit an event, or when music is shared online. But it appeared that to adolescents, although they live in a digital age and share their lives in the social media, physical presence is important. Collins emphasises that the physical component of rituals is decisive: their 'starting point is when human bodies come together in the same place' (Collins 2004:33). He adds, 'Once the bodies are together, there may take place a process of intensification of shared experience' (Collins 2004:35). In other words, according to Collins, there is no ritual without physicality. This bodily presence and intensification of 'shared experiences' lead us to an elaboration of the second aspect of being together: empathetic and emotional.

\section{'The empathetic period' and 'emotional communities'}

Our late-modern culture enhances the coming into being of fluid identities. Many authors describe these developments from a sociological or psychological point of view, as well as from an ecclesiological point of view (Bauman 2000; Schweitzer 2003; Ward 2002). Within these fluid identities, emotional or experienced connections and small groups are considered to be important, which is convincingly argued by Maffesoli (1996). They are, as indicated by empirical research, connected to youth culture by others (De Kock, Roeland \& Vos 2011; Van Wijnen 2013). We highlight some aspects of what Maffesoli called 'emotional communities' (Maffesoli 1996) and discuss the related notion of 'equality'.

'Emotional communities', in the way Maffesoli (1996:9-30) talks about them, are communities which focus on what unites them rather than on distinctiveness and on what separates them (10). He speaks of our time as an 'empathetic period'. He explains:

The rational era is built on the principle of individuation and of separation, whereas the empathetic period is marked by the lack of differentiation, the 'loss' in a collective subject: in other words, what I shall call neo-tribalism. (p. 11)

We adopt the notion of empathy in this sense. Maffesoli proposes the notion of 'neo-tribalism' to describe the phenomenon of social groups in mass society, loosely organised around shared lifestyles, tastes, interests and affinities (1996:96). It is the desire of being together which connects them (De Kock et al. 2011:336).

De Kock et al. observe tribal socialisation amongst young people in neo-evangelical movements (2011:334). Characteristics of these new communities are:

- a loose type of organisation

- shared lifestyles

- a desire to be together

- the ideal of authenticity (2011:336).

In this empirical study, we observed 'unity \& trust' and 'equality' as important values. These are characteristics of neo-tribalism in the 'empathetic period'. In our research project on youth worship, we observed this type of group formation not only in neo-evangelical movements, but also in more mainstream Christian traditions. 
Nearly all research on adolescents refers to the concept of 'peers'. During adolescence, social relations with peers are of major importance and influence the developmental context (Savin-Williams \& Berndt 1990:277-297; Scholte \& Engels 2007:94-109; Schwartz, Bukowski \& Aoki 2006:314-316). Peers are not necessarily people of exactly the same age, but people of the same social, emotional and cognitive level (Scholte \& Engels 2007:94). In our culture, however, age grouping is the norm in most contexts, such as school, team sports and youth programs (Savin-Williams \& Brendt 1990:284). Mutual socialisation of and cooperation between 'equals' are essentially performed in relations of friends or groups of friends (Savin-Williams \& Brendt speak of 'similarity' 1990:283-286; Scholte \& Engels 2007:97; Schwartz argues [2006:315] that religiosity provides a context for friendship 'by facilitating common ground activities and shared belief systems'. He says 'friendship contributes to spirituality and spirituality contributes to friendship' [2006:316]). These groups as a consequence turn into 'communitas' in the sense that Turner discusses (1969:96-97, 132). Peers clearly influence the participation of adolescents in youth worship. Adolescents, for example, discuss with peers whether to go to the worship gathering or not, the presence of many peers at an event impresses others, and dancing or yelling only happens with friends. The data also contains some signal words which we summarised as 'equality'. One of them is 'coziness', defined as 'the individual pleasure of being together as equals' (Dronkers 2013:104).

\section{Crossing social and ecclesiological boundaries}

A third aspect of 'being together' is the (possibility of) crossing of social and ecclesiological boundaries. This aspect explicitly refers to the above mentioned discussion on the Christian ecclesial core value of unity, also in worship. We prefer the notion of crossing over 'bridging' (Putnam 2000:22-23) or 'linking', as used in studies in social capital (Brouwer 2009:74). The reason is that social capital includes an aspect of functionality (85), ${ }^{5}$ whereas being together in the worship community is mainly gratuitous in nature and serves not primarily functional aims.

\section{Sharing faith}

In theological discourse, the social notion of 'being together' is usually captured in different terms, for instance in the Greek word koinonia. The (worshipping) community is not primarily considered as based on a contractual or emotional connectedness, neither is it seen as a sociological or as a cosmological or natural one, but as a group that participates 'in something that is greater than quality or feeling of any of the individuals or their relations' (Brouwer 2009:11). ${ }^{6}$ We hold the view that sociological and theological notions together explain the phenomenon of youth worship best. In the empirical data that we gained by interviewing adolescents

\section{Brouwer refers to a study by Colclaugh and Sitaraman (2005).}

6.Van Rhijn, Meulink-Korf (1997:390) quoted by R. Brouwer. Dutch: '... iets dat groter is dan eigenschap of gevoel van ieder der leden afzonderlijk of van hun relaties'. who participated in youth worship, community and faith experiences are related and mixed. In the (sociological) being together the (theologically) holy happens. ${ }^{7}$

Participation in something that transcends the individual can be framed theologically with the help of the theories of Friedrich Schleiermacher (1768-1834). His central perspective on lived religion and religious experiences (Gräb 2010:338340 ), is relevant to the late-modern culture, that focus on lived religion and, additionally, religious experiences. He approaches worship from the perspective of solidarity (German: Geselligkeit) of the (worshipping) community. This is of course relevant in terms of reflection on the practice of youth worship, in which being together is indeed a constitutive aspect. Schleiermacher's theology emphasises the importance of sharing with others, and also the sharing of religious experiences. He speaks about the church as 'Cirkulation des religiösen Interesses' ['the circulation of religious interest'] (Schleiermacher 1850:65). He claims that people connect with each other, because of a need to share deep experiences (Schleiermacher 1996:73). The more someone is affected (German: aufregten oder erregten Gefühl), the more he wishes to show it to and share it with others. Schleiermacher speaks of the principle of religious sociability (German: Prinzip der religiösen Geselligkeit) (Schleiermacher 1996:77). ${ }^{8} \mathrm{He}$ considers liturgy as expressions of heightened affections and of representational action (Schleiermacher 1843:509-510). ${ }^{9}$ This representational action is embedded in the community and, thus, has a specific cultural appearance (Schleiermacher 1843:512-513). Schleiermacher explains this in terms of feast and the arts (Barnard 2001:185-204; Schleiermacher 1850:839).

For Schleiermacher, social and psychological dimensions as well as metaphysical dimensions influence the affection and, therefore, the representation. According to him, being touched by the divine is a constitutive element in human awareness (Bewusstsein). Rather than God himself, this religious awareness is an object in liturgy (Schleiermacher 1850:88). In our words, the encounter with God is localised in the human subject as affection. Thus, Schleiermacher gives us a theological framework to describe and understand our empirical data. If we take the liberty to fill the space that Schleiermacher creates by his methodological openness to the divine - as he himself did in his sermons - and if we reduce the distinction between the divine and the religious awareness of the divine, we can say that God works through interhuman communications and relations. Additionally, Andrew Root has advocated a relational approach in Youth Ministry. He argues:

In the construct of person meeting person, or social relationships, the revelation of God breaks into human existence. Because Jesus Christ is person, there is no way into reality but through personto-person encounter. (Root 2007:173)

7 This is a paraphrase of the title of Immink, Het heilige gebeurt (2011). Wuthnow considers community the way to find spirituality and faith (Wuthnow 1994:31).

8.See also Schleiermacher (1958), Über die Religion. Hamburg, S. 1., 104, viewed 21 January 2013 from Permalink: http://www.zeno.org/nid/20009265988

9.German: 'Darstellung', originating from the 'erregten Gefühl'; 'Gefühl' includes both affectedness and consciousness. 
Whereas Root claims a mediating role for Jesus, an approach of relationships in pneumatological terms is also possible.

\section{Method of gathering and analysing empirical data}

In this article, we present 'being together' as an essential quality of participation in youth worship. ${ }^{10}$ The domain of our research project has been youth worship services in local congregations as well as in national (Dutch) and European youth worship events. The local youth worship services that were investigated varied in composition: small groups of adolescents with one to three adult leaders or mixed groups (intergenerational) of young people and adults. The youth worship events that were included in the research project were:

1. a national Christmas event of the youth organisation of the Protestant Church in the Netherlands (JOP), called X-Mas Proof

2. a day of the Evangelical Broadcasting Company, the socalled EO youth day (studied twice in different years)

3. the XNoizz Flevo Festival, a worship festival organised by Youth for Christ together with the EO and JOP organisations already mentioned

4. a European Taizé event in the Netherlands.

During the period of time between January 2007 and December 2012, we have observed eighteen youth worship gatherings, thirteen of them in local congregations in the Protestant Church, and five with a national or European character. The focus in our research was on adolescents in youth worship gatherings between the ages of 15 and 19; a few 14 and 20 year olds have also been included. Both girls and boys were involved as respondents. ${ }^{11}$ The respondents in the research project had a Protestant background. In this research project, a 'Protestant background' refers to a connection with the Protestant Church in the Netherlands (PCN). This church is a merger of churches of Reformed and Lutheran traditions. It is the largest Protestant church in the Netherlands in terms of membership (1.75 million members according to Kaski [2010]).

To understand the participation of adolescents in youth worship, participant observations provided us with data from an etic point of view ('what do they do?') (Stringer 1999:50). We collected data by means of field notes, pictures, and videos. The emic point of view was investigated by means of individual and small group interviews and conversations and email correspondence. This yields the emic point of view ('What do they say they do?'). We also interviewed a leader of the organisation of each of the investigated events.

10.The rationale behind the methodology and the methodological choice is fully described in the introduction of the dissertation. Here we refer to some basic choices concerning domain, data collecting and analysis.

11.There were 44 female and 35 male respondents. Girls: 14 years, $4 x ; 15$ years, $11 x ; 16$ years, $14 x ; 17$ years, $6 x ; 18$ years, $4 x ; 19$ years, $4 x ; 20$ years, $1 x$. Boys: 14 years, $2 x ; 15$ years, $6 x ; 16$ years, $6 x ; 17$ years, $13 x ; 18$ years, $2 x ; 19$ years, $4 x$; 20 years, $2 x$. These numbers are based on the respondents in the small groups 20 years, $2 x$. These numbers are based on the respondents in the small groups
and the individual in-depth interviews, but not on the respondents of the speed interviews.
These interviews gave information about the gathering, its intentions, developments and the broader context. Websites of congregations and events also provided information on the broader context.

We started the research with an open explorative approach, in which, amongst other things, we had an eye for those who participate in youth worship. Our analysis was also open and 'community' emerged as a sensitising concept. We looked for concepts with which to elaborate this aspect. In a later phase of analysing the data and reflection on the results, we decided to speak of 'being together'. We did so because community is more static, whereas being together is more dynamic and includes choices to come or do things together (intentional acts). In our opinion the concept of 'being together' also includes the connotations of all kinds of momentary meetings, more so than the concept of community. Adolescents are together, they share and do things, they meet for one event, and all of this is understood in the concept of 'being together'.

The comparison of data and the literature yielded the following perspectives, which became central in the analysis of the relational or inter-subjective aspects in the participation in youth worship from an emic point of view:

- The experienced relations and social interactions.12

- The (religious, theological) meanings given to the worship community. ${ }^{13}$

- Identity constructions in comparison with other groups. ${ }^{14}$ Individuals have an image of themselves as part of a social group. ${ }^{15}$ Supposed characteristics of the 'other' often function as a mirror for the identity of the self or one's own group.

With regard to the etic perspective, in analysing the data from the participant observation (the perception of the researcher), and the perspective of the organisations, the analytical perspectives were:

- the social interactions ${ }^{16}$

- the social intentions ${ }^{17}$

- elements of crossing social and ecclesiological boundaries. $^{18}$

The meanings and interactions were eventually clustered around the aspects of 'being together' mentioned earlier:

1. Physical presence and interaction

2. Empathetic and emotional aspect (unity\& trust, equality)

12.Such as 'social interaction - Christian friends'; 'social interaction - inter generational'; 'experience of collective'; 'social motives'.

13.Such as 'community supportive', 'connection inter churches', 'God social interaction'.

14.Such as 'we \& other Christians', 'Christians \& non-Christians'.

15.Cohen (1985:58) argues from a symbolic construction theory that the boundaries 'mark the community in relation to other communities'. Brown (2000:xviii) speaks of a comparison theory.

16.Such as 'adolescents are accompanied by parents' or an activity in which the participants have to give each other a blessing whilst putting a bracelet on each other's arms.

17. For example, this perspective refers to an appeal to connect to each other, or to an experience of difficulties in connecting adults and adolescents.

18.Such as 'an adult invited as guest', 'youth organises a service for the congregation', 'parents discuss with children', 'ecumenical meeting'. 
3. Crossing social and ecclesiological boundaries

4. Shared faith action and being in God's presence

\section{Results: Being together in youth worship ${ }^{19}$}

We describe the empirical findings of the various aspects of 'being together' in youth worship. These findings include local worship as well national events, although the presence and interaction with other Christians and the meaning of unity is experienced slightly more strongly by the adolescents at the (extraordinary and crowded) events.

\section{Physical presence}

'Being together' is first of all celebrated by means of physical presence, that is by being together in the same space and involved in the same activity. Physical presence emphasises the visible and corporeal. Adolescents sitting next to each other and chatting, meeting in small groups, sitting in a circle for prayers, hugging, touching each other, flirting, looking at each other, and dancing together at events, are common phenomena in youth worship. Clothing is also an aspect of physical presence. An example of a physical sign of belonging to a specific group or community is a specially designed T-shirt at the EO youth day of 2009. Belonging to the same group was emphasised by wearing this T-shirt with a cross. Also, in the trains back home it led to recognition.

\section{Presence and interaction with other Christians}

The physical presence of other (young) Christians sometimes generated an emotional awareness of 'not being alone' for adolescents. Active participation and visibility of peer performers is emphasised by organisers of youth worship. They accentuate the participation of adolescents in the preparation of the meeting, at the liturgical centre and on the music stages. They look for the visibility of peer performers in more or less leading positions. At the events, some artists and performers are personally known by the adolescents. They join the same broader network. As such, the Christian network reduces the distance between stage and field. Being together and doing things together matter to adolescents, also in local worship: seeing the activity of others, singing or praying together and having conversations is highly appreciated by adolescents.

Interviewer: 'What was your favorite moment?'

Marlies: 'I always really enjoy the prayer with candles. Mostly 'cause that makes me realise how happy I am that we're all able to be together like that. And before the club, if we light something, it makes me really happy, it's good for me.'

Interviewer: 'Why is it good for you?'

Marlies: 'Cause you're all together with such a large group and you're doing stuff together. It's a sense of connectedness. I dunno, just because ...' (Girl, 18, local youth worship service, small group interview 22 April 2007)

19.The quotations of the adolescents have been translated by a professional translator.
At events, the large number of participants influences the experience, more specifically the perception of the intensity and the relevance of the gathering. The crowdedness is considered to be encouraging. Singing with thousands of young people is experienced as stimulating and impressive. Of course, the shadow side of crowdedness is that it may become impersonal. At the EO youth day, we observed attempts to counter this, by putting the spotlights in the crowd on some individuals and by highlighting personal stories. These life and faith stories were meant to encourage others.

An important experience in youth worship events is the presence of Christians of other churches and from other countries. This generates positive and supportive feelings and an awareness of being connected with each other. Adolescents experience that the Church is much broader than one specific congregation and that they are not alone as Christians. The presence of people from abroad (artists, or at the Taizé event ${ }^{20}$, participants from other European countries) creates awareness of bonding all around the world. The affiliation between Christians of different churches and cultures apparently inspires some adolescents to speak ideologically about the importance of connecting between churches.

\section{Presence and interaction: Peers and siblings}

In general, peer groups are important for the development of people in the phase of adolescence. The importance of peers for participating in youth worship is also obvious. Adolescents meet and want to meet peers (friends, school mates, peers from the church, cousins, girlfriends, boyfriends, or other young Christians). We also found an important influence of (older) brothers and sisters on the participation in youth worship. In youth worship, siblings function as peers. Older brothers and sisters invite and stimulate their siblings to participate in youth worship. Some adolescents participate in youth worship because older siblings perform in a youth band or organise the worship. Sometimes siblings introduce younger brothers or sisters in worship. The following quote illustrates this finding:

Interviewer: 'Hey, which group are you here with? [XNFF], ( ... ) How did it come together?'

Marije: $\quad$ 'I just dropped in on it. My sister is older, she's W.'s age. It's through her that I joined the group.' (Girl, age 18, XNFF, interview 19 August 2010)

\section{Presence and interaction: Intergenerational}

The place of and social interaction with adults in a youth worship gathering depend on whether or not the meeting is a categorical youth gathering or an intergenerational mixed assembly with a focus on young people. In small categorical groups, usually found in mainline congregations, adults are absent except for the minister, the leader of the group or an invited guest. In categorical

20.An event organised by the brothers of the community of Taize in France: www. taize.fr in cooperation with local churches. This event can be characterised by silence, specific Taizé hymns, prayer, Bible reading, and meetings. 
events, (young) adults are present as organisers of the trip to the location of the event, as chauffeurs, or as youth leaders or artists. In some cases the respondents were stimulated to join an event by a local youth leader or a school teacher. They are important for the participation of young people in events. A respondent explained that a youth leader functions as the contact person between adults and youngsters. As such, youth leaders have a key role in Christian youth work. ${ }^{21}$

In youth worship gatherings with a more intergenerational dimension, parents are involved as well as other adults. We noticed parents and their children sitting next to each other, but also children sitting next to their peers.

There are tensions between generations when it comes to worship. A minister of a local Reformed-orthodox congregation that was included in the research has expressed the difficulties that the congregation experienced with the objectives of intergenerational worship. Music styles in particular divide the different groups. Another minister asked adults to tolerate youth services on a regular worship moment five times a year, and if they could not, to stay away on those specific occasions.

We observed that adults in most gatherings represent the broader community in its supportive role towards young people: creating a space for being seen, praying for them, being a conversation partner, and giving practical help. The following observation, taken from our field notes, demonstrates this supportive role.

The adolescents stood in the center and adults of the congregation (mostly parents or youth leaders) on the side, at the door gate. In our opinion this symbolises the fact that many parents bring their children or stimulate them to participate, but that in the worship gathering the young people are in the center and the parents on the side, as supporters (chauffeur, organiser, stimulator, member of the congregation, conversation partner). (Field notes in a local youth worship gathering, 26 September 2010)

Input for adolescents also comes from adults as performers, whether artists, youth leaders or ministers, because of what they say and do or who they are.

\section{Empathetic and emotional aspects: Unity \& trust, equality}

The empathetic and emotional aspect of 'being together' can be understood by 'unity and trust' and 'equality'.

\section{Unity and trust}

This 'empathetic and emotional' aspect is emphasised by codes such as 'being and doing together', 'trust others', 'unity' (especially coded at the events). We discuss all these codes in terms of the notions of 'unity and trust':

21.See Schwarz et al. $(2006: 311-313,318)$ about mentoring by youth ministers as a developmental context for spiritual development.
Kai explains a photograph of a candle which he had taken: 'To me a candle always represents the feeling of togetherness. Loving, warm. Together. Well, so that's what I enjoyed about this event too. Being together.' (Boy, 16, X-Mas Proof, interview 23 December 2008)

The experience of unity is indicated with emotional feelings such as experiencing warmth, love, but also the experience of 'coziness' (Dutch: gezelligheid). Music and singing are mentioned as activities in worship which unite people.

The other eminent notion is 'trust', that is, trust in each other and in the group, as well as the experience of being in a 'safe place' or of an atmosphere of 'openness' and 'being known', 'feeling at home'. In some prayers and conversations, adolescents obviously experienced openness to express what worried them. Confidentiality is also considered characteristic of the group:

Renske: 'Yeah, I really admired that, how she's able to talk about it like that in front of a group she doesn't know ...'

Wouter: 'Yeah, well, this is a really confidential group, if you talk about something, no one will blab about it.'

Renske: ' 'but she doesn't know us at all.'

Wouter: 'but there is a sense of confidentiality. You can talk about anything, it's fine.' (Girl Renske, 19, boy Wouter, 17, local youth worship service, small group interview 02 December 2007)

The meaning of 'trust' points to a feeling of unity and vice versa, the experience of being united as Christians may stimulate an experience of openness, as is seen in the following quote:

'At an event, I always enjoy seeing how very kind everyone is towards each other. The many different nationalities made it feel really big and impressive, and you really felt connected to each other, cause we're all Christians or we're all looking for God. I felt really relaxed, because everyone is so different as well and nobody is strange, just because there were so many odd people wandering around.'(Annemarie, girl, 16, Taizé, small group 04 February 2011)

This quote appears to say that what connects (being a Christian) is stronger than what separates ('strange' others).

Doing and sharing activities together is also important for this element of unity and trust. Adolescents share what is important to them and their religious feelings in music, prayers, conversations and in other ways. Trust and related elements like openness are stimulated by reflections of respondents on differences and similarities between Christians and non-Christians, notably at the EO youth day and XNoizz Flevo Festival. A girl mentioned that in comparison with non-Christian festivals, artists can be freely approached (the absence of bodyguards at XNFF), which is not possible at other festivals. When the researcher asked if she went to these other festivals she answered, 'No, but I heard about it'. Freely approaching the artists is highly 
appreciated by this girl, and for her it is a characteristic of this event. Another example is that the (supposed) negative influence of alcohol at secular festivals is criticised by some. In this perspective, 'no-alcohol' positively influences a community of unity and trust, and at the same time it may be regarded as a sign and symbol that expresses the feeling of belonging at Xnoizz (Scharnberg \& Ziebertz 2002:37). ${ }^{22}$

\section{Equality}

'Equality' is another element of the empathetic and emotional aspect of 'being together' that is essential for adolescents. We emphasise this in view of the discussion on separated and mixed worship. 'Equality' is traced, for example, in the analysis of the 'coziness' code in the interviews. We mention this, because coziness is important in youth worship. Coziness is related to notions like harmony and togetherness, but also to sharing the same feelings, attitudes and convictions. 'Equality' does not only depend on coziness. The data show various references to the experience or supposition of sharing the same feelings, same values, same ideas, same background (e.g. being raised in a Christian family), and the same goals, in other words 'recognition' and 'equality'. This equality is crucial to adolescents in youth worship. ${ }^{23}$

'As far as I know, everyone in that space believes in the same God, and shares the same passions. You won't find that same sense of harmony at any other festival.' (Joran, boy, 17, EO youth day, speed interview 13 June 2009)

Being together in youth worship means being together as Christians or at least as people who share a Christian background, as kindred spirits. As we already mentioned, for adolescents the experience of being together as young people is also celebrated in all kinds of peer interactions. This is expressed in the following utterance of a boy at the EO youth day: 'just that you can worship God, together, as young people, that's cool.' Mostly, however, the experience of being together as young Christians is taken as a fact in the interviews, and being together as Christians prevails in the reflections. Aspects of inequality are mentioned when respondents compare faith expressions in regular worship services and youth worship events, or secular events and Christian events.

\section{Border crossing}

\section{Between generations and churches}

As mentioned before, equality matters. This equality, however, does not necessarily mean that groups involved in youth worship are closed groups. At the events, for example, groups connect with other groups from other churches or other spots in Christian networks. Crossings also occur when a guest is invited to tell his or her story and to share faith in a small local worship group. Crossings take place whenactivities

\section{In German: Zugehörigkeitsbezeugungen}

23. Equality does not exclude plurality. In our article 'Educating young people' (Sonnenberg \& Barnard 2012) we also described that differences in opinion stimulate the learning process. or creations from a youth worship gathering are brought into the broader congregation, such as by introducing some creative expressions and central topics of a youth worship gathering in the Sunday morning service. A clear example of a crossing to the regular service is a congregation where the youth group that visited Taizé, afterwards organised a Taizé worship for the entire congregation. Another example of a crossing is that in one of the congregations involved parents talked with their children about 'love and sex' after a youth worship event on this theme. We conclude that youth worship creates possibilities and room for both adults and adolescents to encounter each other, and at the events, for Christians of different places to meet.

\section{Others outside the Christian group}

We also found openness to people who stand at a certain distance from faith or church (friends, siblings, imaged others), as well as reflections on youth in modern secular times in general. This openness is caused by a longing to share a message with people who stand at a certain distance from faith and also by a longing to share positive images of faith and church or to share a supportive atmosphere with outsiders. The following quotes provide information on how this longing is seen:

Henriette: ' ' . . the topics at youth services are often about faith or lack of faith, and not about wow, how great God is or anything. And that's mostly what I read in his word. And of course the call to repent and convert, that's really the basic topic for a youth service. It's as though they always want to convince the young people.'

Mirjam: 'but that really is the goal.'

Henriette: 'of a youth service?'

Mirjam: 'yes, I think that it is a goal [as well? inaudible, authors] in your life to let other people have faith too.' (Two girls, 16, local youth worship gathering, small group interview 13 January 2008)

Kai: 'But isn't it great that the event is added to try to make today's young people get a bit excited about faith. Or at least to keep them excited. There is more and more secularisation nowadays, so yeah, that's a pity, isn't it.' (Boy, 16, X-Mas Proof, interview 23 December 2008)

In a study on the EO youth day, the Dutch sociologist Duits (2009) describes how subcultures usually exist because of boundaries, but that at the EO youth day going beyond one's own 'subculture' is essential to young people. First of all we conclude, with Duits (2009:29), that the ('secular') other is important to adolescents, because they see it as their mission to involve others (including youth in general) in faith. In our data, this openness is not always explicitly motivated by an urge to converse, as Duits concludes. Secondly, we also concur with her that adolescents show a kind of longing for a recognition of the relevance of youth worship by other peers. We noticed this, indirectly, in quotes concerning other peers who can see that 'it is not only boring in church', and in the 
wish for a 'greater number' of young people involved, which appears to indicate relevance.

\section{Shared faith and being in God's presence}

In various interviews the experience of being together is explicitly connected with faith experiences. These experiences take different forms as religious inspiration or as a reference to God as an actor. We observed some differences in gatherings of mainline congregations and more Reformed-orthodoxevangelical gatherings in this regard, but faith experiences of adolescents show a gliding scale and cannot necessarily be reduced to a single type of confessional congregation.

$\begin{array}{ll}\text { Daan: } & \text { 'The youth service] gives me inspiration }{ }^{24} \text { for } \\ & \text { life', but that's mostly because of the different } \\ \text { experiences of other people. And 'I enjoyed } \\ \text { the service 'cause of engaging with a theme } \\ \text { together. For me, it's mainly the social life and } \\ \text { talking about faith is something I find really } \\ \text { interesting too, to see how everyone thinks } \\ \text { about it.' } \\ \text { (Boy, 20, local youth worship gathering, small } \\ \text { group interview 02 December 2007) } \\ \text { 'What does this day have to do with faith, for } \\ \text { Interviewer: } \\ \text { you?' } \\ \text { 'Faith is something you need to do together! } \\ \text { And that's really what's being fulfilled today! } \\ \text { All of us believing together and worshipping } \\ \text { Our Dear Lord!' (Girl, 16, EO youth day, mail } \\ \text { interview } 29 \text { June 2009) }\end{array}$

Some respondents, especially girls, ${ }^{25}$ connect the experience of being together to experiences of God's presence. They mostly do so after a question about the relation between the gathering and God or faith.

Interviewer: 'I just asked about faith. If you were to put it in your own words, what part did God have in this celebration?'

Gea: 'I felt that he [God] was there in the congregation, with the actual people. And that when you see other people being happy about it, and talking about it, that's when I feel that he's there, or in conversations if you're talking about him.' (Girl, 15, local youth worship service, small group interview 04 March 2007)

Others connect faith and community in a more general sense, for example, with words that express 'feeling safe' as in the following quote, or by referring to 'being together (as Christians)'.

Eline: 'At a school party or at the pub you're not
engaging with God at all. And at X-Mas Proof
you are engaging with it in a fun way. It always
makes me feel great to join in with something
like that. You're with your friends and I
always feel like God is with you as well then. less explicitly and less obviously than some girls.
There are always moments when your friends wander off, because they've seen something else, but especially at X-Mas Proof I don't even feel as if I'm alone for a few minutes. It gives me a feeling of being safe.' (Girl, 15, X-Mas Proof, added email correspondence at interview 23 December 2008)

Being together in a worship group and doing things together, are connected with faith. If one can say that it, thus, becomes a 'sacred experience', it is an experience related to the presence of others. The quality of being together in youth worship may be described as having the potential of being a sacred quality. The feeling of community has social and psychological connotations and is open to something of God that may be revealed.

\section{Summary and conclusion}

The question that we answer in this article is: What aspects can be distinguished in the quality of 'being together' in youth worship and how can they be understood sociologically and theologically? We found the physical presence, empathetic and emotional aspects, the crossing of social and ecclesiological boundaries, and sharing faith as core aspects of 'being together' in youth worship. We also found the sociological perspective and the theological perspective to be strongly interconnected when analysing our empirical data.

Concerning the physical and empathetic and emotional aspects we conclude the following. Firstly, in our data, there are many references to cozy meet and greets, singing together, being in each other's presence, having face-toface conversations, seeing others moving on the music. Collins argues that physical presence stimulates a process of (emotional) intensification. This physical presence of seeing others and being with others is important in youth worship. Secondly, empathetic and emotional aspects of being together are prominent in the broad field of youth worship. We summarise the experiences and appreciation of unity, the importance of a community which you can trust and where you feel at home, with the terms 'unity and trust'. The other element is 'equality' on which we will reflect in the next paragraph. With the importance of the emotional aspects in the whole youth worship practice, the findings of this research extend, to other groups, the conclusions of De Kock et al. (2011) with regard to young people in the neoevangelical movement.

Thirdly, equality is an important element of being together, it refers to kindred spirits. We add this notion to the characteristics that De Kock and others attribute to evangelical neo-tribes: loosely organised, shared lifestyles, desire to be together, the ideal of authenticity. Equality stimulates the (cozy) connection between actors. In sharing religious feelings, recognition (of values, backgrounds, ideas) is an important element. We argue that in some situations, a lack of equality in other worship models may serve as an argument for separated youth worship. 
Fourthly, older brothers and sisters invite and stimulate their siblings to participate in youth worship. They are key persons with regard to the participation of adolescents in youth worship. We recommend further research into the role of (older) siblings in youth ministry. In human development research the influence of sibling socialisation recently received special attention, whereas this focus seems to be lacking in research on youth ministry until now (Kramer \& Cong 2009).

Concerning the aspect of crossing boundaries, we argue that the ideal of intergenerational worship does not always match with the practice. There is a strong need to experience equality. However, categorical youth worship also yields possibilities to cross social boundaries (e.g. between adults and young people) and ecclesiological ones. Concerning the policy of youth worship we recommend comprehensive reflections on creative possibilities for crossing social and ecclesiological boundaries in and by youth worship. This crossing may also be a topic for discussion with young people themselves. Openness on the part of the adult community may be part of the answer to contributing to the crossing aspect. ${ }^{26}$

The aspect of 'sharing faith', as we discussed it, clearly proves that sociological and theological frameworks overlap. The relevance of sharing religious experiences with others is obvious. Schleiermacher states that people connect with each other, because of a need to share deep experiences. This need builds a community of experts and religious equals (Schleiermacher 1996). The social character of worship is one of the main reasons for the participation of adolescents in youth worship and is often connected by them with faith experiences or even the presence of God. Therefore, we propose to speak of the sacred presence of the Other and others. In the context of youth worship we see that 'the holy happens' means that God works through and in inter-human communications and relations and that these relations condition the presence of God.

Christian worship is characterised by the feature of being together with other Christians. We end with the general conclusion that this feature for youth asks for equality factors, as well as openness to others. Moreover, in the presence of others, also the presence of the Other may happen.

\section{Acknowledgements}

\section{Competing interests}

The authors declare that they have no financial or personal relationships which may have inappropriately influenced them in writing this article.

\section{Authors' contributions}

All authors are responsible for the research design. P.M.S. (Protestant Theological University [PThU]) collected

26.The theologian Firet speaks in the context of education of 'equi-human', which refers to an appreciation of the humanity of the pupil. Firet (1986), Dynamics in pastoring, 156,162,164,169. This is of value to whoever is involved in the ministry for and with youth. and analysed the empirical data, whilst M.B. and A.d.K. (Protestant Theological University [PThU]) and M.N. (University of Pretoria) fulfilled the role of supervisors involved in the research.

\section{References}

Barnard, M., 2001, 'Secular feast and Christian feast in Schleiermacher's practical theology and aesthetics. A theoretical contribution to the study of liturgy and the arts', in P. Post, G. Rouwhorst, L. Van Tongeren \& A. Scheer (eds.), Christian feast and festival: The dynamics of western liturgy and culture, pp. 185-204, Peeters, Leuven.

Bauman, Z., 2000, Liquid modernity, Blackwell Publishers, Oxford/Malden, MA.

Brouwer, R., 2009, Geloven in gemeenschap. Het verhaal van een protestantse geloofsgemeenschap, Kok, Kampen.

Brown, R., 2000, Group processes. Dynamics within and between groups, Blackwell Publishers Ltd., Oxford.

Cloete, A.L., 2015, 'Living in a digital culture: The need for theological reflection', HTS Teologiese Studies/Theological Studies 71(2), Art. \#2073, 7 pages. http://dx.doi. org/10.4102/hts.v71i2.2073.

Cohen, A.P., 1985, The symbolic construction of community, Tavistock, London. http:// dx.doi.org/10.4324/9780203323373

Collins, R., 2004, Interaction ritual chains, Princeton University Press, Princeton, NJ. http://dx.doi.org/10.1515/9781400851744

De Kock, A., 2015, 'Schools and religious communities' contributions to the religious formation of Christian youth', International Journal of Christianity and Education 19(2), 121-134. http://dx.doi.org/10.1177/2056997115583428

De Kock, A., Roeland, J. \& Vos, P.H., 2011, 'Beyond individualization. Neo-evangelical lessons for religious socialization', Journal of Beliefs \& Values 32(3), 329-342. http://dx.doi.org/10.1080/13617672.2011.627699

Dronkers, P., 2013, 'Spelbrekers: Hoe gezellig is het nieuwe wij?', in M. Kalsky \& N. de Jong (reds.), Alsof ik thuis ben. Samenleven in een land vol verschillen, pp. 99-114, Parthenon, Almere.

Duits, L., 2009, 'Ondersteboven van Jezus op de EO-Jongerendag', in M. Aerts \& M van den Haak (reds.), Popvirus: Popularisering van cultuur en religie, pp. 14-33, Aksant, Amsterdam.

Emery-Wright, S., 2012, Now that was worship. Hearing the voices of young people, Cliff College Publishing, Derbyshire.

Firet, J., 1986, Dynamics in pastoring, Eerdmans, Grand Rapids, MI.

Gräb, W., 2010, 'Schleiermacher's conception of theology and account of religion as a constitutive element of human culture', in B.W. Sockness \& W. Gräb (eds.), Schleiermacher, the study of religion, and the future of theology. A transatlantic dialogue, pp. 335-348, De Gruyter, Berlin.

Hahn, F., 1970, Der urchristliche Gottesdienst (SBS 41), Verlag Katholische Bibelwerk Stuttgart, Stuttgart.

Immink, F.G., 2011, Het heilige gebeurt. Praktijk, theologie en traditie van de protestantse kerkdienst, Boekencentrum, Zoetermeer.

Kaski, 2010, Kerncijfers 2010, viewed 06 December 2012, from http://www.ru.nl/ kaski/onderzoek/cijfers-overige/virtuele_map/kerncijfers-2010/.

Kramer, L. \& Cong, K.J. (eds.), 2009, Siblings as agents of socialization: New directions for child and adolescent development, Jossey-Bass, San Francisco, CA. (Special issue: Siblings as agents of socialization, 126).

Maffesoli, M., 1996, The times of the tribes: The decline of individualism in mass society, Sage, London.

Nel, M., 2000, Youth ministry. An inclusive congregational approach, Design Books, Pretoria.

Putnam, R.D., 2000, Bowling alone, the collapse and revival of American community, Simon \& Schuster, New York, NY.

Root, A., 2007, Revisiting relational youth ministry: From a strategy of influence to a theology of incarnation, InterVarsity Press, Downers Grove, IL.

Savin-Williams, R.C. \& Berndt, T.J., 1990, 'Friendship and peer relations', in S.S. Feldman \& G.R. Elliott (eds.), At the threshold. The developing adolescent, pp. 277-297, Harvard University Press, Cambridge.

Scharnberg, C. \& Ziebertz, H.G., 2002, Weltjugendtag 2002 Forschungsbericht zur Fragebogenuntersuchung, Universität Würzburg, Würzburg.

Schleiermacher, F.D.E., 1843, Die Christliche Sitte nach den Grundsätzen der evangelischen Kirche in Zusammenhange dargestellt, G. Reimer, Berlin.

Schleiermacher, F.D.E., 1850, Die Praktische Theologie nach den Grundsätzen der evangelischen Kirche im Zusammenhange dargestellt, G. Reimer, Berlin.

Schleiermacher, F.D.E., 1958, Über die Religion, viewed 21 January 2013, from http:// www.zeno.org/nid/20009265988.

Schleiermacher, F.D.E., 1996, On religion. Speeches to its cultured despisers, transl. R. Crouter, Cambridge University Press, Cambridge. http://dx.doi.org/10.1017/ CBO9780511814969

Scholte, R. \& Engels, R., 2007, 'Psychosociale ontwikkeling: de invloed van leeftijdgenoten', in J. de Wit, J \& M. van Aken (eds.), Psychologie van de adolescentie. Basisboek, pp. 94-109, HB Uitgevers, Baarn. 
Schwartz, K.D., Bukowski, W.M. \& Aoki, W.T., 2006, 'Mentors, friends, and gurus: Peer and nonparent influences on spiritual development', in E.C. Roehlkepartain, P.E. King, L.M. Wagener \& P.L. Benson (eds.), The handbook of spiritual development in childhood and adolescence, pp. 310-323, Sage Publications, Thousand Oaks, London and New Delhi. http://dx.doi.
org/10.4135/9781412976657.n22

Schweitzer, F., 2003, Postmoderner Lebenszyklus und Religion. Eine Herausforderung für Kirche und Theologie, Gütersloher Verlagshaus, Gütersloh.

Senter III, M.H., Black, W., Clark, C. \& Nel, M., 2001, Four views of youth ministry and the church: Inclusive congregational, preparatory, missional, strategic, Zondervan Publishing House, Grand Rapids, MI.

Sonnenberg, P.M. \& Barnard, M., 2012, 'Educating adolescents through Christian youth worship. Reclaiming space for learning in liturgical context', HTS Teologiese Studies/Theological Studies 68(2), Art. \#1111, 8 pages. http://dx.doi.org/10.4102/ hts.v68i2.1111

Sonnenberg, P.M. \& Barnard M., 2015, 'Youth worship as recreation', International Journal of Practical Theology 19(1), 138-163. http://dx.doi.org/10.1515/ijpt2014-0024
Sonnenberg, P.M., Nel, M., De Kock, A. \& Barnard, M., 2014, 'Shaping youth worship. Modes of active participation', Questions Liturgiques/Studies in Liturgy 94(3/4) 216-236.

Stringer, M.D., 1999, On the perception of worship. The ethnography of worship in four Christian congregations in Manchester, University Press, Birmingham.

Taizé community in France, viewed 06 November 2010, from www.taizé.fr

Turner, V.W., 1969, The ritual process: Structure and anti-structure, Aldine de Gruyter, New York, NY.

Van Lieburg, F., 2012, Jeugdwerk met een watermerk. De Hervormd-Gereformeerde jeugdbeweging 1910-2010, Boekencentrum, Zoetermeer.

Van Wijnen, H., 2013, 'Connected to the wellspring: An ecclesiology of small groups of adolescents', International Journal for the Study of the Christian Church 13(3), 208-221. http://dx.doi.org/10.1080/1474225X.2013.823035

Ward, P., 2002, Liquid church, Baker Books, Grand Rapids, MI.

Wuthnow, R., 1994, Sharing the journey. Support groups and America's new quest for community, The Free Press, New York, NY. 